\title{
GAMBARAN PERESEPSI TERHADAP RAGAM ALAT KONTRASEPSI MKJP DAN NON MKJP WANITA USIA SUBUR (WUS) DI PROVINSI NUSA TENGGARA BARAT
}

\author{
Dwika Aldila $^{1)}$, Rita Damayanti ${ }^{2}$ \\ Fakutas Kesehatan Masyarakat Universitas Indonesia \\ dwika.aldila@gmail.com
}

\begin{abstract}
ABSTRAK
Alat kontrasepsi merupakan produk yang digunakan oleh akseptor KB untuk memenuhi kebutuhan fertilitasnya. Dengan pilihan alat kontrasepsi yang beragam, akseptor KB memiliki peluang memilih jenis alat kontrasepsi yang digunakan. Berdasarkan tingkat efektifitas alat kontrasepsi untuk mencegah kehamilan, jenis kontrasepsi yang paling efektif adalah Metode Kontrasepsi Jangka Panjang (MKJP). Persepsi akseptor terhadap alat kontraepsi berpengaruh terhadap metode kontrasepsi yang dipilih. Persepsi akseptor yang tidak benar mengenai MKJP menyebabkan ketidaksesuain akseptor memilih alat kontrasepsi. Penelitian ini menggunakan data sekunder ICMM 2016. Penilitian ini menggunakan distribusi frekuensi dan mean untuk mengetahui gambaran persepsi terhadap ragam alat kontrasepsi MKJP dan Non MKJP. Sampel dalam penelitian ini adalah wanita usia subur (WUS) usia 15 - 49 Tahun yang menggunakan alat kontrasepsi di Provinsi Nusa Tenggara Barat (NTB) yang berjumlah 9100 responden. Penelitian ini menunjukan gambaran persepsi preferensi terhadap alat kontrasepsi, persepsi perbandingan kesamaan alat kontrasepsi MKJP dan Non MKJP, persepsi karakteristik alat kontrasepsi yang diinginkan responden terkait kemudahan dan efektivitas, dan persepsi perbandingan kesamaan karakteristik antara alat kontrasepsi MKJP dan Non MKJP. Dalam upaya peningkatan cakupan penggunaan MKJP diperlukkan strategi komunikasi dalam pembuatan program promosi dengan melihat gambaran persepsi akseptor terhadap ragam alat kontrasepsi yang akan mereka pilih atau mereka gunakan.
\end{abstract}

Kata Kunci: Keluarga Berencana, Alat Kontrasepsi Jangka Panjang, Persepsi Alat Kontrasepsi

\section{PENDAHULUAN}

Keluarga berencana (KB) adalah tindakan yang membantu individu atau pasangan suami istri untuk mendapatkan objektif-objektif tertentu, menghindari kelahiran yang tidak diinginkan, mendapat kelahiran yang memang diinginkan, mengatur interval diantara kehamilan, mengontrol waktu saat kehamilan dalam hubungan dengan umur suami istri dan penentu jumlah anak dalam keluarga (BKKBN, 2009). Program $\mathrm{KB}$ adalah bagian yang terpadu (integral) dalam program pembangunan nasional dan bertujuan untuk ikut serta menciptakan kesejahteraan penduduk Indonesia, untuk mencapai keseimbangan yang baik (Depkes, 2006).

Di Indonesia berdasarkan hasil SDKI 2017 menunjukkan bahwa 64\% wanita kawin berusai 15-49 tahun menggunakan alat $\mathrm{KB}, 57 \%$ diantaranya menggunakan alat kontrasepsi modern. Wanita kawin yang menggunakan alat kontrasepsi 13\% diantaranya menggunakan Metode Kontrasepsi Jangka Panjang (MKJP) yang terdiri dari IUD, Implan dan tubektomi (operasi pada perempuan). Alat kontrasepsi suntik KB merupakan alat kontrasepsi yang paling banyak digunakan oleh wanita kawin menurut hasil SDKI 2017 yaitu 29\%, diikuti oleh pil 12\%, susuk KB dan IUD (masing-masing 5\%), dan tubektomi 4\%. 
Meskipun alat/cara KB modern di anatara wanita kawin meningkat dari SDKI 2002/03 sampai SDKI 2012, namun sedikit turun pada SDKI 2017.

Pemerintah lebih menganjurkan MKJP berdasarkan pertimbangan non MKJP tidak ekonomis dan efisien dibandingkan MKJP (BKKBN, 2012). MKJP lebih efisien dibandingkan non MKJP dalam ketersediaan anggaran dan penyediaan kontrasepsi serta lebih efektif karena tingkat efek samping, komplikasi dan tingkat kegagalan lebih rendah $(\mathrm{BKKBN}, 2012)$. Winner $\mathrm{B}$, et al (2012), menyebutkan dengan menggunakan MKJP selain akan menghemat biaya pengeluaran seseorang tidak perlu sering berkunjung untuk memperoleh alat kontrasepsi kembali serta cepat mengembalikan kesuburan. Rendahnya pengunaan MKJP WUS dikhawatirkan dapat menimbulkan dampak terhadap upaya penurunan fertilitas yang lebih cepat. Persepsi terhadapa suatu produk (alat konrasepsi) akan mempengaruhi perilaku konsumen (akseptor KB) dan adanya pemahaman yang salah dan mitos mengenai alat kontrasepsi menyebabkan pilihan yang tidak tepat akseptor terhadap alat kontrasepsi (Moreau, Cleland, \& Trussel, 2007).

\section{METODE}

Penelitian ini adalah jenis peneltian kuantitatif Penelitian ini menggunakan data sekunder dari Pusat Penelitian Kesehatan (PPK) Fakultas Kesehatan Masyarakat Universitas Indonesia berupa baseline data penelitian Improving Contraceptive Mix Methode (ICMM) di Nusa Tenggara Barat tahun 2016 sehingga variabel pada penelitian ini bergantung dari tersedianya variabel pada kuesioner ICMM 2016. Populasi dalam penelitian ini adalah wanita usia subur (WUS) yang berusia 15-49 Tahun yang berasal dari Kabupaten Lombok utara, Kabupaten Lombok Tengah dan Kabupaten Bima, Provinsi NTB. Sampel adalah sebagian dari jumlah dan karakteristik yang dimiliki oleh populasi (sugiyono, 2014) maka dari itu, sampel adalah wanita usai subur (WUS) 15 -49 tahun yang terpilih menjadi responden penelitian ICMM. Untuk memperoleh gambaran dari variabel yang diteliti maka data dianalisis secara univariat.

\section{HASIL \& PEMBAHASAN}

\section{Persepsi Preferensi Alat Kontrasepsi}

Variable persepsi preferensi alat kontrasepsi dibagi menjadi dua kelompok yaitu MKJP dan Non MKJP. Variabel ini merupakan persepsi terhadap preferensi keinginan responden untuk menggunakan alat kontrasepsi. Pada tabel 5.1 menampilkan distribusi persepsi preferensi MKJP dan Non MKJP dilihat dari nilai mean, SD dan nilai minimum dan maksimum. 
Tabel 1

Distribusi Jawaban Responden Mengenai Persepsi Preferensi Alat Kontrasepsi

\begin{tabular}{llllc}
\hline \multirow{2}{*}{ Metode Kontrasepsi } & \multicolumn{1}{c}{$\begin{array}{c}\text { Preferensi Alat } \\
\text { Kontrasepsi }\end{array}$} & Mean & SD & Min-Mak \\
\hline \multirow{2}{*}{ Non MKJP } & Pil & 41.84 & 29.873 & $0-100$ \\
\cline { 2 - 5 } & Suntik & 71.31 & 28.098 & $0-100$ \\
\hline \multirow{2}{*}{ MKJP } & IUD & 32.61 & 28.604 & $0-100$ \\
\cline { 2 - 5 } & Implant & 37.38 & 30.775 & $0-100$ \\
\hline
\end{tabular}

Tabel 2

Distribusi Persepsi Preferensi Berdasarkan Jenis alat Kontraepsi yang Digunakan

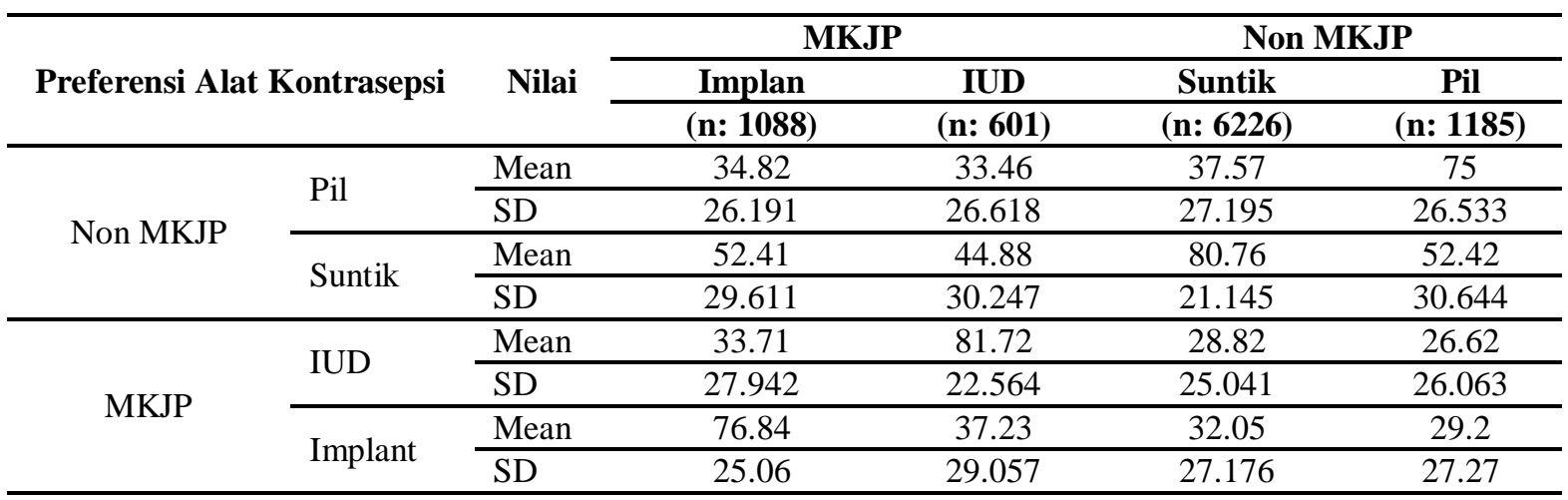

Tabel 2 menggambarkan distribusi frekuensi persepsi preferensi alat kontrasepsi MKJP dan Non MKJP. Pada tabel dapat dilihat kecenderungan responden yang menggunakan alat kontrasepsi memiliki preferensi nilai mean yang paling besar terhadap alat kontrasepsi yang mereka gunakan. Mislanya, Responden yang mengunakan alat kontrasepsi pil akan memiliki preferensi dengan nilai mean yang besar pada alat kontrasesi pil, responden yang menggunaan suntik memiliki preferensi yang besar pada alat kontrasepsi suntik, responden yang menggunakan IUD memiliki nilai mean yang besar pada preferensi IUD, begitu juga responden yang menggunakan alat kontrasepsi implant akan memiliki nilai mean yang besar pada alat kontrasepsi implant.

\section{Persepsi Perbandingan Kesamaan Alat Kontrasepsi}

Variabel kesamaan alat kontrasepsi merupakan persepsi responden terkait perbandingan kesamaan alat kontrasepsi MKJP dan Non MKJP. Variabel ini menampilkan jawaban responden yang melihat niali mean, SD dan nilai minimum dan maksimum dari skala 0 -100 (tidak sama - sama persis). 
Tabel 3

Distribusi Jawaban Responden Mengenai Persepsi Kesamaan Alat Kontrasepsi

\begin{tabular}{lccc}
\hline \multicolumn{1}{c}{$\begin{array}{c}\text { Perbandiangan Alat } \\
\text { Kontrasepsi }\end{array}$} & Mean & SD & Min-Mak \\
\hline Pil dan IUD & 31.63 & 19.157 & $0-100$ \\
\hline Pil dan Implan & 31.56 & 20.001 & $0-100$ \\
\hline Suntik dan IUD & 33.49 & 19.984 & $0-100$ \\
\hline Suntik dan Implan & 34.51 & 20.904 & $0-100$ \\
\hline
\end{tabular}

Tabel 4

Distribusi Persepsi Kesamaan Alat Kontrasepsi Berdasarkan Jenis alat Kontrasepsi yang Digunakan

\begin{tabular}{llcccc}
\hline \multirow{2}{*}{\begin{tabular}{c} 
Kesamaan Alat $\begin{array}{c}c \\
\text { Kontrasepsi }\end{array}$ \\
\cline { 2 - 6 }
\end{tabular}} & Nilai & \multicolumn{2}{c}{ MKJP } & \multicolumn{2}{c}{ Non MKJP } \\
\cline { 2 - 6 } Pil dan IUD & Mean & 31.03 & 31.04 & 31.44 & 33.49 \\
\cline { 2 - 6 } & SD & 17.639 & 19.109 & 19.071 & 20.818 \\
\hline Pil dan Implan & Mean & 32.39 & 30.96 & 31.23 & 32.87 \\
\cline { 2 - 6 } & SD & 19.748 & 19.205 & 19.859 & 21.277 \\
\hline Suntik dan IUD & Mean & 34.07 & 34.00 & 33.25 & 33.93 \\
\cline { 2 - 6 } & SD & 20.029 & 20.138 & 19.767 & 20.975 \\
\hline Suntik dan Implan & Mean & 35.41 & 35.17 & 34.05 & 35.74 \\
\cline { 2 - 6 } & SD & 21.476 & 20.443 & 20.688 & 21.654 \\
\hline
\end{tabular}

Distribusi frekuensi pada tabel 4 menunjukkan bahwa rata-rata responden memiliki persepsi kesamaan terhadap alat kontrasepsi dengan nilai mean paling tinggi 35.74 yaitu responden yang menggunakan alat kontrasepsi pil yang memiliki persepsi kesamaan pada alat kontrasepsi suntik dan Implan sedangkan nilai mean paling kecil yaitu, 30,96 yaitu responden pada kelompok IUD yang memiliki persepsi kesamaan pada alat PIl dan Implan.

\section{Persepsi Karakteristik Alat Kontrasepsi}

Variabel persepsi karakteristik alat kontrasepsi dibagi menjadi dua yaitu kemudahan dan efektifitas yang merupakan persepsi responden terhadap hal yang dianggap sangat penting dan tidak penting terhadap alat kontrasepsi.

Tabel 5

Distribusi Jawaban Responden Mengenai Karakteristik Alat Kontrasepsi

\begin{tabular}{llcc}
\hline \multicolumn{1}{c}{ Karakteristik Alat Kontrasepsi } & Mean & SD & Min-Max \\
\hline Mudah digunakan & 82.13 & 14.481 & $0-100$ \\
\hline Mudah didapatkan & 82.10 & 14.871 & $0-100$ \\
\hline $\begin{array}{l}\text { Efektif/manjur/kemungkinan gagal } \\
\text { kecil untuk mencegah kehamilan }\end{array}$ & 80.49 & 15.688 & $0-100$ \\
\hline Tidak ada efek samping & 80.87 & 18.381 & $0-100$ \\
\hline Tahan lama/tidak perlu berulang-ulang & 79.30 & 17.796 & $0-100$ \\
\hline
\end{tabular}


Tabel 6

Distribusi Persepsi Karakteristik Alat Kontrasepsi Berdasarkan Jenis alat Kontrasepsi yang Digunakan

\begin{tabular}{|c|c|c|c|c|c|}
\hline \multirow[b]{2}{*}{ Karakteristik Alat Kontrasepsi } & \multirow[b]{2}{*}{ Nilai } & \multicolumn{2}{|c|}{ MKJP } & \multicolumn{2}{|c|}{ Non MKJP } \\
\hline & & $\begin{array}{l}\text { Implan } \\
(\mathbf{n}: \mathbf{1 0 8 8})\end{array}$ & $\begin{array}{c}\text { IUD } \\
(n: 601)\end{array}$ & $\begin{array}{l}\text { Suntik } \\
(\mathrm{n}: 6226)\end{array}$ & $\begin{array}{c}\text { Pil } \\
\text { (n: } \\
\text { 1185) }\end{array}$ \\
\hline \multirow[t]{2}{*}{ Mudah digunakan } & Mean & 81.26 & 81.93 & 82.06 & 83.36 \\
\hline & SD & 14.552 & 15.350 & 14.350 & 14.585 \\
\hline \multirow[t]{2}{*}{ Mudah didapatkan } & Mean & 80.46 & 83.18 & 80.06 & 81.42 \\
\hline & SD & 15.790 & 14.866 & 15.809 & 15.200 \\
\hline \multirow{2}{*}{$\begin{array}{l}\text { Efektif/manjur/kemungkinan gagal } \\
\text { kecil untuk mencegah kehamilan }\end{array}$} & Mean & 81.22 & 82.75 & 81.92 & 83.55 \\
\hline & SD & 15.048 & 14.573 & 14.958 & 14.300 \\
\hline \multirow[t]{2}{*}{ Tidak ada efek samping } & Mean & 81.37 & 83.37 & 80.38 & 81.74 \\
\hline & SD & 17.964 & 17.297 & 18.508 & 18.497 \\
\hline \multirow{2}{*}{$\begin{array}{l}\text { Tahan lama/tidak perlu berulang- } \\
\text { ulang }\end{array}$} & Mean & 80.50 & 83.71 & 78.62 & 79.54 \\
\hline & SD & 17.955 & 16.026 & 17.849 & 17.865 \\
\hline
\end{tabular}

Tabel 6 merupakan distribusi jawaban responden mengenai karakteristik alat kontrasepsi yang dilihat berdasarkan kemudahan dan efektifitasnya. Pada tabel di atas rata-rata karakteristik kemudahan dan efektifitas memiliki nilai mean yang tinggi, hal ini menunjukkan bahwa responden memiliki persepsi bahwa karakteristik alat kontrasepsi merupakan salah satu yang penting terutama karakteristik kemudahan (mudah didapat dan mudah digunakan) yang memiliki nilai mean yang lebih besar dibandingakan efektifitas.

\section{Persepsi Kesamaan Karakteristik Alat Kontrasepsi}

Variabel persepsi kesamaan karakteristik alat kontrasepsi merupakan jawaban responden terhadap perbandingan karakteristik alat kontrasepsi (kemudahan dan efektifitas) yang melihat persepsi responden terhadap kesamaan kedua karakteristik tersebut dengan skala 0 -100 (tidak sama - sama persis).

Tabel 7

Distribusi Jawaban Responden Mengenaik Kesaman Karakteristik Alat Kontrasepsi

\begin{tabular}{llll}
\hline \multicolumn{1}{c}{$\begin{array}{c}\text { Perbandingan Karakteristik Alat } \\
\text { Kontrasepsi }\end{array}$} & Mean & SD & Min-Max \\
\hline Mudah digunakan/praktis dan efektif & 54.55 & 24.026 & $0-100$ \\
\hline Mudah digunakan dan tidak ada efek samping & 52.09 & 25.224 & $0-100$ \\
\hline Mudah digunakan dan tahan lama & 51.69 & 25.785 & $0-100$ \\
\hline Efektif dan mudah didapatkan & 51.29 & 25.589 & $0-100$ \\
\hline Mudah didapatkan dan tidak ada efek samping & 50.66 & 26.334 & $0-100$ \\
\hline Mudah didapatkan dan tahan lama & 50.02 & 26.576 & $0-100$ \\
\hline
\end{tabular}


Tabel 8

Distribusi Persepsi Kesamaan Karakteristik Alat Berdasarkan Jenis alat Kontrasepsi yang Digunakan

\begin{tabular}{|c|c|c|c|c|c|}
\hline \multirow{2}{*}{$\begin{array}{c}\text { Perbandingan } \\
\text { Karakteristik Alat } \\
\text { Kontrasepsi }\end{array}$} & \multirow[b]{2}{*}{ Nilai } & \multicolumn{2}{|c|}{ MKJP } & \multicolumn{2}{|c|}{ Non MKJP } \\
\hline & & $\begin{array}{c}\text { Implan } \\
\text { (n: 1088) }\end{array}$ & $\begin{array}{c}\text { IUD } \\
(n: 601)\end{array}$ & $\begin{array}{c}\text { Suntik } \\
\text { (n: 6226) }\end{array}$ & $\begin{array}{l}\text { Pil } \\
(n: \\
1185)\end{array}$ \\
\hline \multirow{2}{*}{$\begin{array}{l}\text { Mudah } \\
\text { digunakan/praktis dan } \\
\text { efektif }\end{array}$} & Mean & 54.49 & 55.13 & 54.10 & 56.69 \\
\hline & SD & 23.433 & 24.164 & 23.945 & 24.810 \\
\hline \multirow[t]{2}{*}{$\begin{array}{l}\text { Mudah digunakan dan } \\
\text { tidak ada efek samping }\end{array}$} & Mean & 52.31 & 52.63 & 51.41 & 55.15 \\
\hline & SD & 24.595 & 25.670 & 25.239 & 25.281 \\
\hline \multirow{2}{*}{$\begin{array}{l}\text { Mudah digunakan dan } \\
\text { tahan lama }\end{array}$} & Mean & 52.66 & 52.89 & 50.89 & 54.41 \\
\hline & SD & 25.760 & 26.012 & 25.657 & 26.159 \\
\hline \multirow{2}{*}{$\begin{array}{l}\text { Efektif dan mudah } \\
\text { didapatkan }\end{array}$} & Mean & 51.41 & 51.29 & 50.85 & 53.46 \\
\hline & SD & 25.449 & 25.054 & 25.536 & 26.176 \\
\hline \multirow{2}{*}{$\begin{array}{l}\text { Mudah didapatkan dan } \\
\text { tidak ada efek samping }\end{array}$} & Mean & 50.78 & 51.01 & 50.12 & 53.26 \\
\hline & $\mathrm{SD}$ & 26.022 & 26.454 & 26.242 & 26.912 \\
\hline \multirow{2}{*}{$\begin{array}{l}\text { Mudah didapatkan dan } \\
\text { tahan lama }\end{array}$} & Mean & 50.64 & 50.27 & 49.40 & 52.60 \\
\hline & SD & 26.597 & 26.918 & 26.485 & 26.720 \\
\hline
\end{tabular}

Pada tebel diatas menunjukkan distribusi frekuensi jawaban responden mengenai kesamaan karakteristik alat kontrasepsi. Rata-rata responden menjawbab pada nilai mean berada pada skor 50 hal ini menunjukkan bahwa responden cendereng menggap bahwa kedua karakteristik (kemudahan dan efektifitas) memiliki kesamaan.

\section{KESIMPULAN DAN REKOMENDASI}

Penelitian ini menunjukan bahwa persepsi preferensi terhadap alat kontrasepsi suntik memiliki nilai mean tertinggi dibandingkan dengan persepsi preferensi alat kontrasepsi yang lain, persepsi kesamaan alat kontrasepsi menunjukan bahwa responden cenderung menganggap bahwa alat kontrasepsi MKJP ( IUD dan Susuk) dan Non MKJP (Pil dan Suntik) tidak sama, sedangkan persepsi karakteristik alat kontrasepsi yang diinginkan responden yaitu terkait kemudahan yaitu mudah digunakan dan mudah didapat selanjutnya, responden menggap bahwa kesamaan karakteristik antara alat kontrasepsi MKJP dan Non MKJP memiliki kesamaan. Dalam upaya peningkatan cakupan penggunaan MKJP diperlukkan strategi komunikasi dalam pembuatan program promosi dengan melihat gambaran persepsi akseptor terhadap ragam alat kontrasepsi yang akan mereka pilih atau mereka gunakan. 


\section{UCAPAN TERIMA KASIH}

Terima kasih kepada Pusat Penelitian Kesehatan (PPK) UI dan ICMM (Improving Contraceptive Mix Methode)

\section{REFERENSI}

1. Badan Pusat Statistik. 2018. Survei Demografi dan Kesehatan Indonesia (SDKI) 2017. Jakarta: Badan Pusat Statistik.

2. BKKBN. (2012). Pedoman Pelayanan Keluarga Berencanan Pasca Persalinan Di Fasilitas kesehatan. Jakarta: BKKBN

3. BKKBN. (2017). Laporan Kinerja Kementerian Kesehatan Republik Indonesia. 2006. "Kesehatan Reproduksi dan Keluarga Berencana."

4. Moreau, C., Bouyer, J., Bagos, N., Rodrigues, G \& Trussell, J. (2009). Frequency of discontinuation of contraceptive use: result from a french population-based cohort. Humas Reproduction, 24 (6): 1387-1392.

5. Sugiyono. (2014). Metode Penelitian Pendidikan Pendekatan Kuantitatif, Kualitatif, dan R\&D. Bandung: Alfabeta 